\title{
Роль помощи
}

\section{международному развитию в достижении целей и задач, поставленных в Декларации тысячелетия}

Л.М. Капица

\begin{abstract}
В статье анализируются предварительные итоги реализации рекомендаций Саммита тысячелетия $\mathrm{OOH}$, отмечаются тревожные симптомы замедления намеченных темпов их реализации. Автор пытается выявить факторы, которые сдерживают выполнение странами-донорами обязательств по поддержке развивающихся стран в их усилиях по преодолению нищеты и отсталости.
\end{abstract}

$\mathrm{H}$ а ряде международных конференций, происходивших после Второй мировой войны, сообщество доноров неоднократно принимало на себя обязательства содействовать ускоренному социально-экономическому развитию бедных и слаборазвитых стран. К сожалению, лишь немногие из этих обязательств были выполнены. Каждый раз, подводя итоги очередной международной стратегии развития, принятой и одобренной на Генеральной Ассамблее $\mathrm{OOH}$, страны-члены с разочарованием констатировали значительное расхождение между заявленными целями и задачами и реальными результатами ее имплементации.

Следует заметить в этой связи, что наряду с объективными факторами, сдерживавшими развитие слаборазвитых стран, значительную роль сыграли также геополитические приоритеты мировых держав, проявившиеся как в селективном подходе к выбору стран-реципиентов, так и направлений помощи развитию. В результате лишь небольшой группе слаборазвитых стран удалось преодолеть отставание и вырваться из ловушки нищеты (в частности, так называемым новым индустриальным странам - НИС). Большинство же стран развивающегося мира по-прежнему сохраняют черты колониальных экономик, продолжая воспроизводить нищету и отсталость.

Критикуя сообщество доноров, необходимо помнить, что в целом никто, ни один донор и ни одна международная организация, какими бы мощными они не казались, не могут компенсировать отсутствие политической воли и твердой решимости правительств и национальных элит стран-реципиентов вырвать их отечества из «ловушки отсталости». Это не только справедливо для развивающихся государств, но и для ряда стран с переходной экономикой. С другой стороны, не вызывает сомнений и тот факт, что при определенных условиях международная помощь развитию может сыграть роль катализатора и подтолкнуть (ускорить) трансформационные процессы в стране-реципиенте. Конечно, лишь очень ограниченный круг развивающихся стран обладает необходимыми предпосылками для совершения такого броска:

- соответствующим социальным капиталом; - большим пулом рабочей силы;

- благоприятными климатическими условиями;

Капица Лариса Михайловна - к.э.н., профессор кафедры мировой экономики МГИМО(У) МИД России. E-mail: vestnik@mgimo.ru 


\section{- Иностранная помощь и развитие}

- выгодным географическим положением;

- наличием важнейших для промышленного развития полезных ископаемых.

Проблема большинства современных беднейших стран состоит также в том, что они не располагают достаточным потенциалом в силу:

- либо чрезвычайно малого размера территории;

- либо низкого уровня развития человеческих ресурсов;

- либо узкой специализации экономики в международном разделении труда;

- либо в силу раздирающих их разного рода проявлений трайбализма ${ }^{1}$.

Нельзя забывать и о том, что беднейшие страны мира должны решать задачи догоняющего развития в исторических условиях, принципиально отличающихся от тех, в которых западноевропейские страны догоняли Великобританию. Как в количественном, так и в качественном отношении нынешний этап мирового развития, подстегиваемый достижениями науки и техники, транснационализацией и интернационализацией торгово-экономических, политических и культурных связей, отличается от предыдущих как скоростью, масштабностью, так и глубиной преобразований. Совершенно очевидно, что необходимы объединенные усилия всех стран мира, чтобы вывести беднейшие страны из их социально-экономического застоя. В свете вышесказанного Саммит тысячелетия 2000 г. представляет еще одну попытку мобилизовать мировое сообщество на решение этой беспрецедентной по своим масштабам в истории международных отношений задачи.

Наконец, необходимо также принимать во внимание и тот факт, что, за исключением международных договоров, все другие договоренности в рамках ООН, включая обещания оказать помощь развитию, не носят обязательный характер. Именно по этой причине помощь международному развитию характеризуется высокой степенью неопределенности и волатильности.

Саммит тысячелетия: цели, задачи и обязательства стран-членов КСР ОЭСР. Цели тысячелетия в области развития ООН - это восемь целей, к достижению которых в 2015 г. договорились стремиться все государства-члены организации, то есть 191 страна (в 2000 г.). Декларация тысячелетия ООН, принятая в сентябре 2000 г., обязывает мировых экономических лидеров - наиболее развитые государства, - бороться с нищетой, голодом, болезнями, неграмотностью, деградацией окружающей среды и дискриминацией женщин. Все цели, выведенные из этой декларации, имеют конкретные задачи и показатели (см. табл. 1).

Страны-доноры обязались предоставить в первую очередь помощь тем странам, которые будут наиболее последовательно проводить политику, направленную на сокращение бедности. В качестве же индикаторов выполнения обязательств странами-донорами были отобраны следующие:
- общий объем чистой помощи (удельный вес в ВНД стран-доноров) и объем чистой помощи, предоставленной наименее развитым странам (\% ВНД);

- пропорция помощи, предоставленной на обеспечение основных социальных потребностей, в двусторонней секторальной помощи стран-доноров;

- пропорция несвязанной помощи в двусторонней помощи стран-доноров;

- пропорция полученной помощи в ВНД стран, не имеющих выхода к морю;

- пропорция полученной помощи в ВНД стран, расположенных не малых островах.

Цели и задачи, сформулированные в Декларации тысячелетия ООН.

\begin{tabular}{|c|c|}
\hline Цели & Задачи \\
\hline $\begin{array}{l}\text { 1. Ликвидация крайней } \\
\text { нищеты и голода }\end{array}$ & $\begin{array}{l}\text { 1. Сократить вдвое долю } \\
\text { населения, имеющего доход } \\
\text { менее } 1 \text { доллара в день }\end{array}$ \\
\hline $\begin{array}{l}\text { 2. Обеспечение всеобщего } \\
\text { начального образования }\end{array}$ & $\begin{array}{l}\text { 2. Сократить вдвое долю } \\
\text { населения, страдающего от } \\
\text { голода }\end{array}$ \\
\hline $\begin{array}{l}\text { 3. Поощрение равенства } \\
\text { мужчин и женщин и } \\
\text { расширение прав и } \\
\text { возможностей женщин }\end{array}$ & $\begin{array}{l}\text { 3. Обеспечить для всех } \\
\text { мальчиков и девочек } \\
\text { возможность получать в } \\
\text { полном объеме начальное } \\
\text { школьное образование }\end{array}$ \\
\hline $\begin{array}{l}\text { 4. Сокращение детской } \\
\text { смертности }\end{array}$ & $\begin{array}{l}\text { 4. Ликвидировать, желательно } \\
\text { к } 2005 \text { году, неравенство между } \\
\text { полами в сфере начального } \\
\text { и среднего образования, а не } \\
\text { позднее чем к } 2015 \text { году - на } \\
\text { всех уровнях образования }\end{array}$ \\
\hline $\begin{array}{l}\text { 5. Улучшение охраны } \\
\text { материнства }\end{array}$ & $\begin{array}{l}\text { 5. Сократить на две трети } \\
\text { смертность среди детей в } \\
\text { возрасте до } 5 \text { лет }\end{array}$ \\
\hline $\begin{array}{l}\text { 6. Борьба с ВИЧ/СПИДом, } \\
\text { малярией и другими } \\
\text { заболеваниями }\end{array}$ & $\begin{array}{l}\text { 6. Снизить на три четверти } \\
\text { коэффициент материнской } \\
\text { смертности }\end{array}$ \\
\hline $\begin{array}{l}\text { 7. Обеспечение } \\
\text { экологической } \\
\text { устойчивости }\end{array}$ & $\begin{array}{l}\text { 7. Остановить распространение } \\
\text { ВИЧ/СПИДа и положить начало } \\
\text { тенденции к сокращению } \\
\text { заболеваемости }\end{array}$ \\
\hline \multirow[t]{4}{*}{$\begin{array}{l}\text { 8. Формирование } \\
\text { глобального партнерства в } \\
\text { целях развития }\end{array}$} & $\begin{array}{l}\text { 8. Остановить распространение } \\
\text { малярии и других основных } \\
\text { болезней и положить начало } \\
\text { тенденции к сокращению } \\
\text { заболеваемости } \\
\end{array}$ \\
\hline & $\begin{array}{l}\text { 9. Включить принципы } \\
\text { устойчивого развития } \\
\text { в страновые стратегии и } \\
\text { программы и обратить вспять } \\
\text { процесс утраты природных } \\
\text { ресурсов }\end{array}$ \\
\hline & $\begin{array}{l}\text { 10. Сократить вдвое } \\
\text { долю людей, не имеющих } \\
\text { постоянного доступа к чистой } \\
\text { питьевой воде }\end{array}$ \\
\hline & $\begin{array}{l}\text { 11. К } 2020 \text { году обеспечить } \\
\text { существенное улучшение } \\
\text { жизни, как минимум, } 100 \\
\text { миллионов обитателей трущоб }\end{array}$ \\
\hline
\end{tabular}


На последующих международных форумах были сформулированы уже конкретные целевые показатели в области помощи международному развитию. Так, в Брюссельской Декларации и Программе действий для наименее развитых стран, принятых на Третьей конференции $\mathrm{OOH}$ по наименее развитым странам в 2001 г., были сделаны следующие рекомендации:

«а) страны-доноры, выделяющие более $0,20 \%$ ВНП в качестве официальной помощи развитию (ОПР) для НРС: продолжают делать это и наращивают свои усилия;

b) другие страны-доноры, вышедшие на целевой показатель $0,15 \%$ : принимают меры для скорейшего достижения уровня в $0,20 \%$;

c) все другие страны-доноры, которые обязались выйти на уровень $0,15 \%$ : подтверждают свои обязательства и принимают меры к тому, чтобы либо достичь этого уровня в течение ближайших пяти лет, либо приложить максимум усилий для ускорения решения этой задачи;

d) в период осуществления Программы действий остальные страны-доноры: предпринимают в индивидуальном порядке максимум усилий для увеличения своей доли ОПР для НРС с тем, чтобы:

- коллективно значительно увеличить объем помощи НРC;

- поддерживать усилия НРС по развитию информационных систем, которые регистрируют, на уровне страны-получателя, показатели и другую соответствующую информацию, касающуюся эффективности помощи как по отдельным донорам, так и по сообществу доноров в целом, путем предоставления материально-технических средств для создания таких информационных систем и подготовки специалистов по их эксплуатации» ${ }^{2}$.

На Международной конференции по финансированию развития, состоявшейся в Монтеррее (Мексика) в марте 2002 г., был достигнут консенсус по целому ряду важнейших проблем в области финансирования международного развития, включая ОПР для развивающихся стран. Страны-участницы конференции призвали доноров «предпринять конкретные усилия для достижения целевого показателя выделения развивающимся странам ОПР в объеме 0,7 процента от валового национального дохода (ВНД) и в объеме $0,15-0,20$ процента от ВНД развитых стран на нужды наименее развитых стран...»³.

В последующие годы страны-доноры неоднократно подтверждали свои намерения выполнить взятые на себя международные обязательства по оказанию экономической помощи развивающимся странам. В частности, на совещании «Большой восьмерки» в июле 2005 г. в Глениглсе, крупнейшие страны-доноры обещали увеличить объем помощи развивающимся странам на 50 млрд долл. (относительно уровня 2004 г.) к 2010 г., в том числе Африке - на 25 млрд долл. Страны Евросоюза, в свою очередь, установили индивидуальный целевой показатель ОПР для 15 стран ЕС («старых членов») в размере $0,51 \%$ ВНД к 2015 г. и групповой - в размере $0,7 \%$ ВНД, а для «новых членов» ЕС, соответственно 0,17\% и 0,33\% ВНД. И, наконец, в 2009 г. страны «Большой восьмерки» на совещании в Аквиле обязались мобилизовать 20 млрд долл. в течение трех лет для обеспечения устойчивого развития сельского хозяйства и оказания адекватной чрезвычайной продовольственной помощи развивающимся странам.

Что же касается стран-доноров, не входящих в Комитет содействия развитию ОЭСР, то члены группы БРИКС, в первую очередь Китай, взяли на себя обязательство предоставить развивающимся странам льготные кредиты на сумму 26 млрд долл. в период с 2000 по 2008 годы.

Выполнение решений Саммита тысячелетия: предварительные итоги. Мониторинг процесса выполнения решений Саммита тысячелетия свидетельствует о сохраняющемся разрыве между обязательствами стран-доноров и достигнутыми результатами, хотя нельзя не отметить, что практически все заинтересованные стороны в той или иной мере степени внесли свой вклад в их реализацию (см. табл. 2). Так, объем ОПР стран-членов КСР ОЭСР вырос до 129 млрд долл. к 2010 г., достигнув 0,32\% их совокупного ВНД. Вместе с тем лишь пять стран-членов КСР оказали помощь в объеме, превышающем целевой показатель ООН - 0,7\% ВНД. Именно поэтому дефицит помощи, согласно докладу Целевой группы по оценке прогресса в достижении целей развития тысячелетия от 2011 г., составил 153 млрд долл. .

Таблииа 2

Оказанная помощь в соотношении с обстоятельствами доноров - членов КСР.

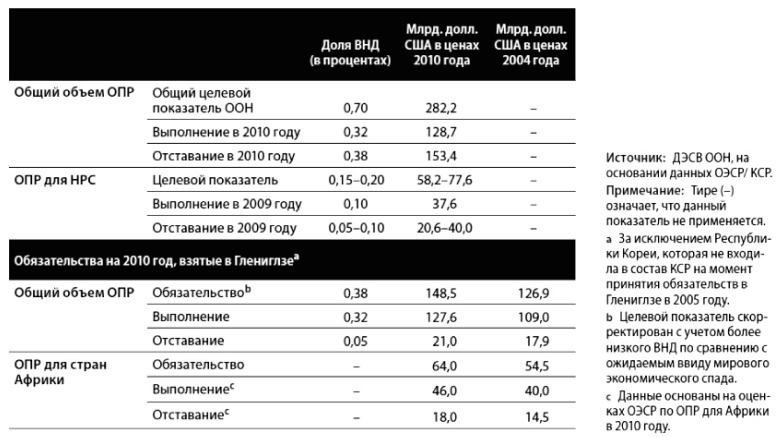

Доклад также отмечает, что доноры увеличили и объем помощи наименее развитым странам (НРC), однако он все еще не достиг целевых показателей. В 2009 г. страны - члены КСР предоставили НРС в виде ОПР 37 млрд долл., что составляет $0,10 \%$ их совокупного ВНД, что намного ниже целевого показателя ООН, установленного между 0,15 и $0,20 \%$ ВНД (см. рис. 1 и 2). В абсолютных величинах дефицит составлял от 21 до 40 млрд долл. Другие группы развивающихся стран, находящиеся в неблагоприятных условиях и которым ООН уделяла особое внимание, в частности страны Африки, малые островные государства (МОСТРАГ) и развивающиеся страны, не имеющие выхода к морю (РСНВМ), также получали ОПР в возрастающем объеме, но не в 


\section{- Иностранная помощь и развитие}

том, который требовался. В целом же ОПР, как и прежде, оказывается в значительной степени сконцентрированной (см. табл. 3). Более $25 \%$ общего объема помощи стран-членов КСР приходилось на десять развивающихся стран. Многие развивающиеся страны, остро нуждающиеся в финансовых ресурсах, получают помощь в объеме, который вряд ли может оказать какое-либо существенное влияние на их внутреннее социально-экономическое состояние.

Таблица 3

«Любимчики» доноров: удельный вес отдельных стран в помощи развитию странчленов КСР.

\begin{tabular}{|l|l|}
\hline $\mathbf{2 0 0 5}$ г. & 2009 г. \\
\hline Нигерия - 5,9\% & Эфиопия - 3\% \\
\hline Ирак - 20,3\% & Танзания - 2,3\% \\
\hline Афганистан - 2,6\% & Палестинская администрация \\
& 2,4\% \\
\hline Индонезия - 2,3\% & Афганистан - 4,7\% \\
\hline Вьетнам - 1,8\% & Вьетнам - 2,9\% \\
\hline Итого: 29,9\% & $15,3 \%$ \\
\hline
\end{tabular}

Источник: Statistics on Resource Flows to Developing Countries. Development Co-operation Directorate, February 2011, OECD, Paris, 201.

Рисунок 1. Географическое распределение чистой

двусторонней ОПР стран-членов КСР, в млн. долл

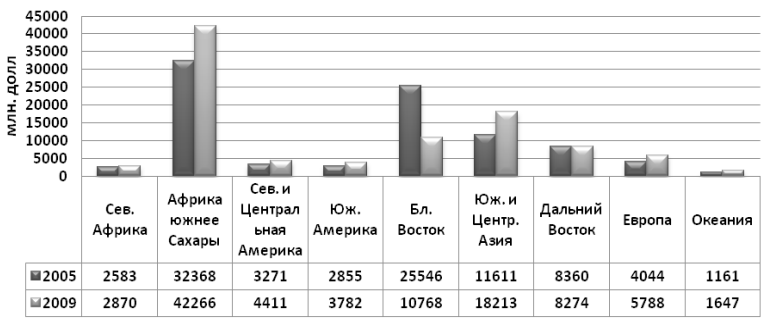

Рисунок 2. Распределение чистой двусторонней ОПР стран-членов КСР по группам развивающихся стран, в млн. долл

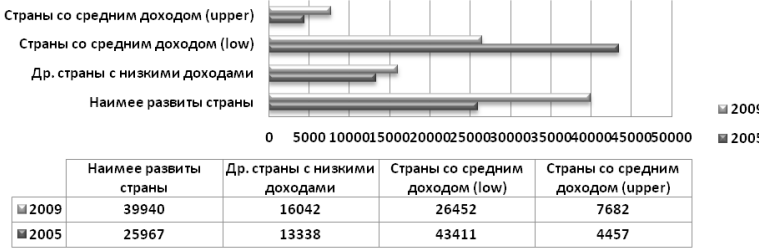

Источник: Statistics on Resource Flows to Developing Countries. Development Co-operation Directorate, February 2011, OECD, Paris, 2011.

Концентрация двусторонней помощи странчленов КСР на небольшой группе развивающихся государств свидетельствует о том, что доноры продолжают использовать помощь в первую очередь как инструмент своей внешней политики. В частности, она направлялась на цели обеспечения безопасности (Ирак, Индонезия, Афганистан, Палестинская администрация, Эфиопия), а также получение доступа к энергоносителям (Ирак, Нигерия и Индонезия).

В свою очередь, секторальное распределение двусторонней помощи тоже вызывает ряд вопросов относительно приоритетов ОПР стран-членов КСР. Так, например, доля социальной и административной инфраструктуры в общем объеме ОПР выросла с 24,8\% в 1988-1989 гг. до 43\% в 2009 г., что в целом совпадает с приоритетами международного развития Декларации тысячелетия. Однако, как видно из табл. 4, лишь 12,5\% из этого объема помощи были израсходованы на развитие государственной администрации и гражданского общества (то есть НПО), тогда как на цели образования было выделено 9\% (в том числе на начальное образование $-2,2 \%$ ), здравоохранения $-4,6 \%$ (в том числе на базовые медицинские услуги - 3,3\%), на развитие водоснабжения и канализации - 3,3\%. Такая структура распределения ОПР, на наш взгляд, не совсем совпадает с целями и задачами Декларации тысячелетия, которая на первый план выдвигает задачи , связанные с развитием человеческих ресурсов и улучшения условий жизни в развивающихся странах.

Таблица 4

Секторальное распределение двусторонней ОПР ${ }^{5}$ стран-членов КСР ОЭСР, в \%.

\begin{tabular}{|c|c|c|c|}
\hline Сектор & $1988-1989$ rr. & $2008-2009$ гг. & 2009 r. \\
\hline $\begin{array}{l}\text { Социальная и } \\
\text { административная } \\
\text { инфраструктура: } \\
\text { 1. образование, в том } \\
\text { числе } \\
\text { начальное образование; } \\
\text { 2. здравоохранение, в } \\
\text { том числе } \\
\text { базовые медицинские } \\
\text { услуги; } \\
\text { 3. водоснабжение и } \\
\text { канализация; } \\
\text { 4. государственная } \\
\text { администрация и } \\
\text { гражданское общество }\end{array}$ & 24,8 & 40,7 & $\begin{array}{l}42,7 \\
8,8 \\
2,2 \\
4,6 \\
3,3 \\
6,2 \\
12,5\end{array}$ \\
\hline $\begin{array}{l}\text { Экономическая } \\
\text { инфраструктура: } \\
\text { 1. транспорт и } \\
\text { коммуникации; } \\
\text { 2. энергетика; } \\
\text { 3. др. }\end{array}$ & 21,5 & 15,9 & $\begin{array}{l}14,9 \\
7,4 \\
3.6 \\
3,9\end{array}$ \\
\hline Сельское хозяйство & 10,6 & 4,5 & 4,7 \\
\hline $\begin{array}{l}\text { Промышленность } \\
\text { и другие виды } \\
\text { производства }\end{array}$ & 7,2 & 2,0 & 1,0 \\
\hline $\begin{array}{l}\text { Помощь в натуральной } \\
\text { форме (товарами) и } \\
\text { программная помощь: } \\
\text { 1. программная помощь, } \\
\text { в том числе } \\
\text {-облегчение долговой } \\
\text { зависимости; } \\
\text { 2. продовольственная } \\
\text { помощь }\end{array}$ & 18,4 & 4,8 & $\begin{array}{l}5,0 \\
2,6 \\
4,0\end{array}$ \\
\hline $\begin{array}{l}\text { Гуманитарная помощь } \\
\text { 1. административные } \\
\text { издержки }\end{array}$ & 1,8 & 8,2 & $\begin{array}{l}8,7 \\
5,2\end{array}$ \\
\hline Др. виды помощи & 15,6 & 23,9 & \\
\hline $\begin{array}{l}\text { Меморандум: доля } \\
\text { двусторонней помощи, } \\
\text { распределяемой через } \\
\text { НПО }\end{array}$ & & 5,9 & \\
\hline
\end{tabular}

Источник: Statistics on Resource Flows to Developing Countries. Development Co-operation Directorate, February 2011, OECD, Paris, 2011. 
Наблюдается относительное сокращение официальной помощи на цели развития материальной сферы экономик развивающихся государств. Удельный вес экономической инфраструктуры в общем объеме ОПР снизился с 21,5\% в 1988-1989 гг. до 15\% в 2009 г., тогда как удельный вес сельского хозяйства - с $10,6 \%$ до $4,7 \%$. Такая же участь постигла промышленное производство, доля которого сократилась за указанный период с $7,2 \%$ до $1 \%$. Не совсем понятно, как такой подход доноров согласуется с основной целью Декларации тысячелетия сокращением бедности. Сложившееся секторальное распределение помощи вызывает наибольшее беспокойство и ставит под сомнение достижение целевых показателей Декларации тысячелетия к установленному сроку. Без развития материального производства, создания рабочих мест и подготовки национальных кадров проблем отсталости и массовой нищеты не решить.

В последнее время страны-доноры уделяют больше внимание вопросам эффективности и координации ОПР, чем реализации целей и задач Декларации тысячелетия. Несомненно, что и эти вопросы относятся к числу важных проблем. Содействуя подготовке государственных управленцев и формированию различных неправительственных объединений, страны-доноры надеются, что это позволит снизить издержки ОПР и повысить ее эффективность, передав в руки местных специалистов управление помощью. Однако, на наш взгляд, надежды доноров, что им удастся «пересадить» современные управленческие институты и внедрить механизмы, обеспечивающие взаимодействие власти и общества в развивающиеся страны, кажутся несколько утопическими.

Как показывает прошлый опыт многих развивающихся стран, такие попытки, как правило, приводили к симбиозу традиционных и имплантируемых институтов, в котором чаще всего побеждали первые. Для современных институтов, порожденных индустриальным обществом, необходимы соответствующие социально-экономические условия, чтобы они функционировали сообразно целям, для выполнения которых они и создавались. В этой связи нелишне вспомнить опыт послевоенной Европы, в частности Германии, где главную роль в восстановлении и модернизации экономики сыграли человеческий и социальный капитал. Принимая же во внимание доминирование традиционных институтов и родоплеменных отношений во многих странах Африки, трудно поверить, что имплантированные институты и практики, управляемые небольшим пулом подготовленных донорами административных кадров, смогут радикально изменить сложившуюся ситуацию и подстегнут трансформационные процессы.

В отношении перспектив двусторонней ОПР стран-членов КСР на ближайшее будущее многие аналитики высказывают сомнение, что страныдоноры смогут выполнить свои обещания относительно дальнейшего наращивания объема помощи, хотя страны-доноры заверили международное сообщество на Саммите ООН по ЦРТ 2010 г. (г. Нью-Йорк), что они предпримут все необходимые для этого усилия. В докладе Целевой группы ООН по оценке прогресса в достижении целей развития тысячелетия отмечается, что «недавний мировой финансово-экономический кризис привел к серьезным отступлениям в достижении целей развития тысячелетия. Но многие страны уже находятся (или вновь находятся) на пути к достижению, по крайней мере, некоторых из целей, поставленных на 2015 год. Подавляющее же большинство стран с низким уровнем дохода отстают по всем ЦРТ, отчасти потому, что были отброшены от этих целей дальше всех» ${ }^{6}$.

Принимая во внимание вышеназванные факторы, Целевая группа ООН обратилась к странамдонорам со следующим призывом: «В будущем, давая обещания, члены КСР должны стремиться обеспечить их ясность посредством обозначения всех параметров, по которым будут оцениваться эти обещания:

- сопоставимость, позволяющую сводить воедино различные обещания стран-доноров;

- реалистичный подход, учитывающий финансово-экономическое положение каждого донора;

- соизмеримость, основывающуюся на доступных или предоставленных показателях;

- ответственность по отношению к получателям помощи и их потребностям;

- прозрачность, допускающую мониторинг со стороны бенефициаров» ${ }^{7}$.

Страны-члены КСР финансируют более 200 различных многосторонних организаций, принимающих участие в содействии международному развитию. Все эти организации можно объединить в две группы:

1) «Большую шестерку», включающую институты ЕС, на которые приходится 37\% многосторонней ОПР стран КСР; МАР МБРР (21\% многосторонней ОПР); фонды и программы ООН (10\% многосторонней ОПР), Африканский банк развития и Азиатский банк развития (на которые приходится соответственно $4 \%$ и $3 \%$ многосторонней ОПР стран КСР);

2) все остальные многочисленные многосторонние организации, на которые приходится $18 \%$ многосторонней ОПР стран КСР ${ }^{8}$.

В период с 1989 г. по 2008 г. многосторонняя ОПР стран-членов КСР выросла с 23 млрд долл. до 35 млрд долл. Удельный вес многосторонней ОПР стран КСР в общем объеме всей их ОПР, если исключить «облегчение долга», составил 27-33\% в указанный период. Следует также отметить, что многосторонняя ОПР стран-членов КСР росла преимущественно за счет их взносов в институты ЕС. Многосторонняя же ОПР другим международным организациям, исключая группу МБРР, в долгосрочном плане имела тенденцию к понижению (см. рис. 3).

Страны-члены КСР весьма отличаются друг от друга по структуре «портфеля ОПР». Напри- 


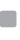

Иностранная помощь и развитие

мер, 13\% многосторонней ОПР Люксембурга и 53\% многосторонней ОПР Германии, если исключить взносы в институты ЕС, приходятся на МАР МБРР. Удельный вес основных фондов и программ ООН в многосторонней ОПР Франции составляет лишь $5 \%$, а Норвегии - $45 \%$. Крупнейшими донорами многосторонней ОПР являются США, Австралия, Норвегия и Испания. Такой разброд в предпочтениях доноров вызван напряженностью, которая возникает между двусторонним и многосторонним участием в содействии международному развитию.

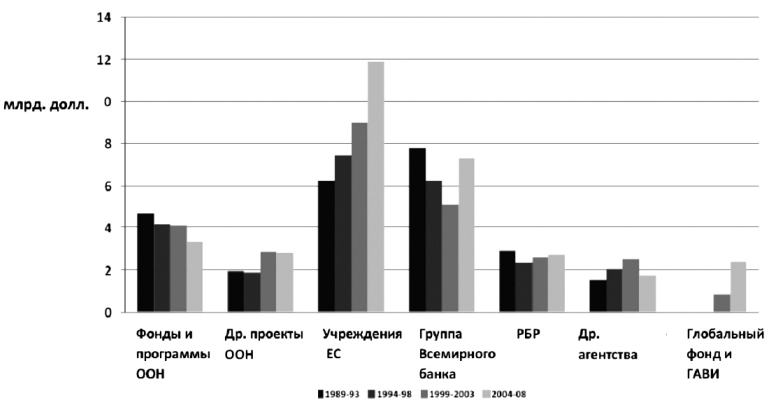

Рис.3. Реальная многосторонняя ОПР стран-иленов КСР, в млрд долл., в постоянных иенах 2008 г.

${ }^{*}$ РБР - региональные банки развития.

Источник: OECD. 2010 DAC Report on Multilateral Aid. Paris, September 2010.

Предоставляя помощь развивающимся странам в рамках двусторонних отношений, стране-донору легче добиться международного признания ее усилий, чем посредством взноса в коллективный пул. Более того, в рамках двусторонних отношений у страны-донора больше возможностей оказывать влияние на распределение помощи в стране-реципиенте. Именно по этой причине в последние годы стало очень популярным среди доноров создавать целевые фонды под эгидой многосторонних организаций (см. рис. 4). В отличие от взносов в основные фонды международных организаций, условия, на которых функционируют целевые фонды, позволяют донорам влиять на распределение средств, направляя их в страны или секторы экономики, которые представляют для них наибольший интерес. Развитие указанной тенденции привело к тому, что доля целевых фондов в многосторонней ОПР стран-членов КСР, если исключить их взносы в институты ЕС, выросла до 39\% к 2008 г. А зависимость фондов и программ ООН от целевого финансирования чрезвычайно увеличилась. Достаточно привести пример ПРООН, одной из ключевых международных программ, нацеленных на реализацию целей и задач Декларации тысячелетия.

В 2008 г. доля целевого финансирования из всех источников в бюджете ПРООН составила $77 \%$ (3,6 млрд долл.), доля основных фондов - 23\% (1,1 млрд долл.). Идентичная ситуация складывается и в финансирование других программ и фондов ООН, что повышает их уязвимость по отношению к любым изменениям в притоке ресурсов ${ }^{10}$.

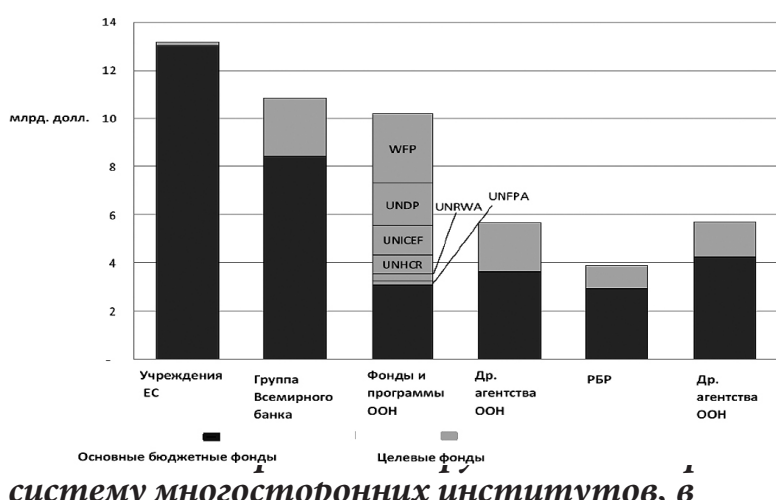

систему многосторонних институтов, $в$ млрд долл., 2008 г.

Источник: OECD. 2010 DAC Report on Multilateral Aid. Paris, September 2010, p. 15.

Многосторонняя ОПР более сфокусирована на целях и задачах Декларации тысячелетия, чем двусторонняя ОПР. Удельный вес Африки южнее Сахары, например, в многосторонней ОПР выше, чем в двусторонней. В 2008 г. он составил $46 \%$ против $27 \%$ в двусторонней ОПР. Многостороння ОПР имеет также большую концентрацию на беднейших странах. На них приходится 75\% против общего объема многосторонней ОПР, тогда как для двусторонней помощи этот показатель составляет 57\%. Вместе с тем, как показывает рис. 5, двусторонняя помощь, по сравнению с многосторонней, более сконцентрирована на самых бедных странах

Секторальное распределение многосторонней ОПР, как видно из рисунка 6 , отличается от двусторонней более высоким удельным весом отраслей производства (9\%), экономической инфраструктуры (19\%) и социальной инфраструктуры (46\%), что, по нашему мнению, в большей степени отвечает задачам Декларации тысячелетия. В то же время следует заметить, что для структуры целевых фондов многосторонней ОПР характерен очень высокий удельный вес помощи так называемым «хрупким государствам» $(72 \%)$, по сравнению с двусторонней $(34 \%)$ и многосторонней помощи, предоставляемой из средств основных фондов международных организаций $(36 \%)$.

Многосторонним организациям, в силу их мандата и присутствия, принадлежит ведущая роль в оказании помощи «хрупким государствам» и странам, находящихся в состоянии конфликта или постконфликтной ситуации. Помимо средств, поступаемых из целевых фондов, $19 \%$ страновой программной помощи многосторонних организаций направляется в страны названных категорий. Некоторые из «хрупких государств» ${ }^{11}$ по геополитическим или экономическим причинам привлекают повышенное внимание государств-доноров (Афганистан, Боливия, Индонезия, Замбия, Узбекистан, Судан, Либерия, Демократическая Республика Конго). В таких случаях удельный вес двусторонней помощи в общем объеме ОПР оказывается выше, чем многосторонней (см. табл. 5). 


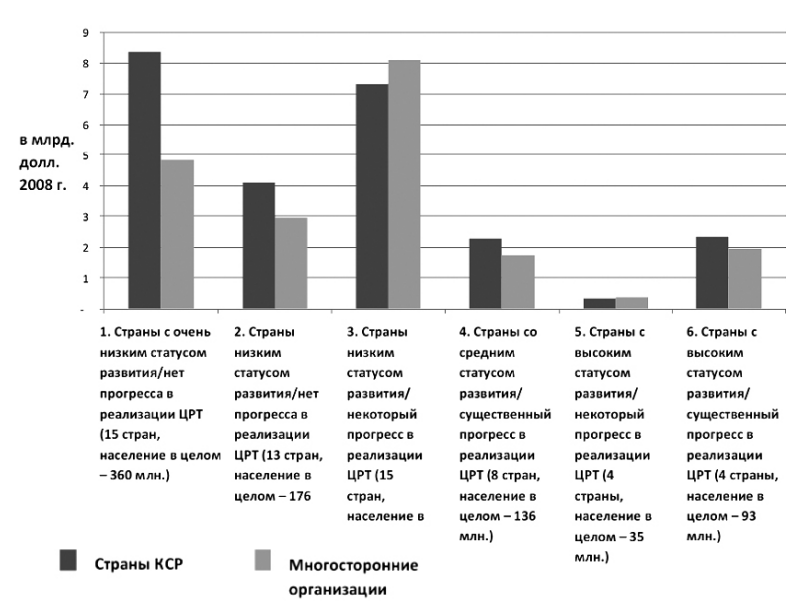

Рис.5. Страновая программная помощь развивающимся странам с низкими доходами, 2009 2. $^{12}$

Источник: OECD. 2010 DAC Report on Multilateral Aid. Paris, September 2010, p. 35.

Целевые фонды, по сути, представляют собой вариант двусторонней помощи, т.к. за донорами сохраняется право распределять средства по своему усмотрению. Неслучайно в статистике помощи ОЭСР целевые фонды обозначены как смешанная, двусторонне-многосторонняя форма помощи. В качестве примера можно привести такие индивидуальные фонды, как: Экологический фонд Франции, Фонд развития человеческих ресурсов Японии (в ПРООН), Японские фонды информационных и коммуникационных технологий и ликвидации бедности (в Азиатском банке развития), Голландская партнерская программа с МБРР, Испанский и бельгийский фонды продовольственной безопасности (в МФСР), Испанский фонд продвижения выполнения ЦРТ (в ПРООН) и др.

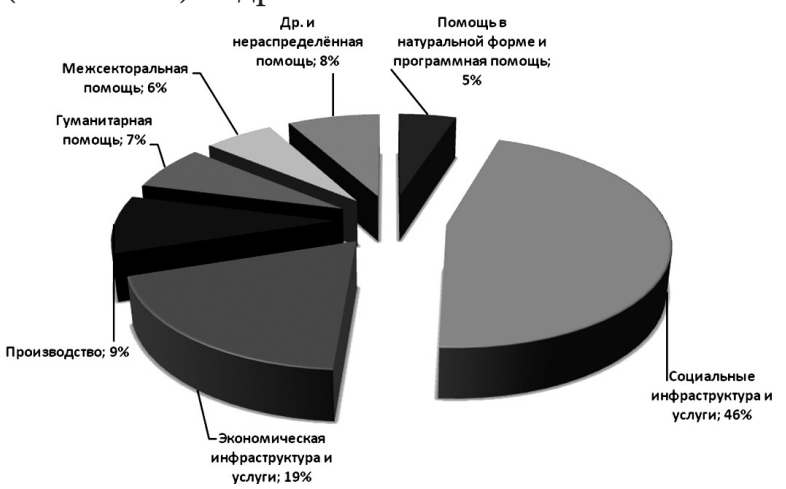

Секторальное распределение многосто-

ронней ОПР, в \%, 2008 г.*

*Исключая облегчение долгового бремени.

Источник: OECD. 2010 DAC Report on Multilateral Aid. Paris, September 2010.

Появился еще два компонента в многосторонней помощи развитию - это целевые трастфонды, финансируемые несколькими странамидонорами, и глобальные фонды. Они так же, как и индивидуальные целевые фонды, контролируются донорами. К подобным траст-фондам относится, например, Фонд реконструкции Ирака, который финансируется 17 странами-донорами. Суммарная сумма взносов доноров в этот фонд составила 494,4 млн долл. на 31 декабря 2009 г.

В некоторых из таких фондов, наряду с агентствами ООН и странами-донорами, участвуют частные корпорации и/или филантропические фонды и другие неправительственные организации. Последние выступают главным образом в качестве канала распределения помощи.

Таблииа 5

Каналы поступления страновой программной помощи в девяти «хрупких государствах».

\begin{tabular}{|l|l|l|l|}
\hline Страна & $\begin{array}{l}\text { Двусторонняя } \\
\text { помощь }\end{array}$ & $\begin{array}{l}\text { Многосторонняя } \\
\text { помощь из целе- } \\
\text { вых фондов }\end{array}$ & $\begin{array}{l}\text { Многосторон- } \\
\text { няя помощь } \\
\text { из основных } \\
\text { фондов }\end{array}$ \\
\hline Афганистан & $65 \%$ & $27 \%$ & $8 \%$ \\
\hline Боливия & $76 \%$ & $6 \%$ & $17 \%$ \\
\hline Гаити & $52 \%$ & $17 \%$ & $31 \%$ \\
\hline Индонезия & $74 \%$ & $7 \%$ & $19 \%$ \\
\hline Монголия & $65 \%$ & $7 \%$ & $28 \%$ \\
\hline Судан & $33 \%$ & $58 \%$ & $9 \%$ \\
\hline Вьетнам & $60 \%$ & $6 \%$ & $34 \%$ \\
\hline Замбия & $72 \%$ & $2 \%$ & $25 \%$ \\
\hline
\end{tabular}

Источник: OECD. 2010 DAC Report on Multilateral Aid. Paris, September 2010, p. 44.

Необходимо остановиться еще на одной тенденции, наблюдаемой в области многосторонней помощи. Как видно из рис. 3, в структуре многосторонней помощи стран-членов КСР, начиная с конца 1990 гг., стали преобладать институты ЕС. В 2004-2008 гг. на их долю приходилось свыше 37\% многосторонней ОПР стран-членов КСР (или 12 млрддолл.), тогда как доля фондов и программ ООН упала с $15 \%$ до $10 \%$ (или 3 млрд долл.). По мнению экспертов ОЭСР такая тенденция была вызвана рядом факторов:

1) изменение в предпочтениях доноров в сторону целевого финансирования;

2) появление новых специальных структур $\mathrm{OOH}$ и глобальных фондов, нацеленных на решение более узких и конкретных задач;

3) отвлечение значительных ресурсов помощи на облегчение долгового бремени развивающихся стран (в 2007 г. на эти было выделено $14 \%$ многосторонней помощи стран-членов, т.е. почти 6 млрд долл.).

На наш взгляд, однако, эти аргументы не раскрывают полностью причин возрастания значения институтов ЕС в многосторонней помощи. Несомненно, налицо результаты развития, по меньшей мере, трех долгосрочных тенденций: консолидация координирующей роли Еврокомиссии в области внешней политики стран-членов ЕC; соперничество между основными мировыми центрами силы за влияние на мировые процессы; эрозия послевоенной архитектуры международного сотрудничества .

Названные тенденции можно воспринимать по-разному, но неслучайно Генеральная Ассам- 


\section{- Иностранная помощь и развитие}

блея (ГА) ООН неоднократно обращалась с призывами к странам-донорам подойти критически к своей практике в области многосторонней помощи развитию. Как считает ГА, дробление ограниченных ресурсов помощи в условиях падения или стагнации взносов в основные бюджетные фонды организаций системы $\mathrm{OOH}$ не способствует ни снижению издержек доставки помощи, ни повышению ее эффективности. Зато в целом повышается вероятность невыполнения целей и задач Декларации тысячелетия.

Kapitsa L.M. The Role of International Development Aid in Realization of Goals and Targets of the Millennium Declaration.

Summary: The article analyses preliminary result of the implementation of the Millennium Summit recommendations. The author notes disturbing symptoms of slowing-down the pace of the Millennium target achievement and attempts to identify factors that constrain donor-countries' fulfillment of their obligations to provide support for developing countries' efforts to overcome absolute poverty and underdevelopment.

\section{Ключевые слова}

Официальная помощь развитию, страна-донор, страна-реципиент, развивающиеся страны, целевые фонды, основные фонды, «хрупкие государства», Саммит тысячелетия, международные обязательства, Комитет содействия развитию, Европейский союз, Всемирный банк.

\section{Keywords}

Official development aid (ODA), donor-country, recipient-country, developing countries, earmarked funds, core funds, "fragile states", Millennium Summit, international obligations, Development Assistance Committee, European Union, the World Bank.

\section{Примечания}

1. Трайбализм - форма общественно-политической племенной обособленности, выражающаяся в формировании органов государственной власти на основе родоплеменных связей. Характерен для стран, где процесс образования нации не завершен. В таких странах наблюдаются постоянные вражда и соперничество между племенами за контроль над институтами правления и соответственно ресурсами.

2. Доклад Третьей конференции ООН по наименее развитым странам. Документы ООН: A/CONF.191/13, 20 September 2001, p. 77.

3. Монтеррейский консенсус Международной конференции по финансированию развития. Принят Международной конференцией по финансированию развития 18-22 марта 2002 года (http://www.un.org/ru/documents/decl_conv/declarations/monterrey.shtml).

4. Глобальное партнерство в целях развития: время выполнять обещания. Доклад Целевой группы по оценке прогресса в достижении ЦРТ, 2011 год. Организация Объединенных Наций, Нью-Йорк, 2011 год.

5. Подсчитано по двусторонней помощи, в среднем по всем странам-членам КСР.

6. Глобальное партнерство в целях развития: время выполнять обещания. Доклад Целевой группы по оценке прогресса в достижении ЦРТ, 2011 год. Организация Объединенных Наций, Нью-Йорк, 2011 год, с.10-11.

7. Там же, стр. 13

8. OECD. 2010 DAC Report on Multilateral Aid. Paris, September 2010, pp. 11-12.

9. Там же, с. 14

10. OECD. 2010 DAC Report on Multilateral Aid. Paris, September 2010, p. 46

11. Термин «хрупкие государства» не является окончательным (или консенсусным), как и критерии, по которым те или иные страны относят к этой категории. Существуют различные типологии «хрупких государств». Так, например, КСР ОЭСР относит к «хрупким государствам» те, которые «не могут удовлетворить ожидания своего населения или ответить на изменения в ожиданиях и возможностях (удовлетворить эти ожидания)». К таким государствам можно отнести: 1) страны, находящиеся в постконфликтной ситуации или переходном (транзитном) политическом состоянии; 2) страны, переживающие кризис государственного правления; 3) страны, в которых наблюдается постепенное, но чрезвычайно медленное улучшение политической ситуации; 4) страны, находящиеся в состоянии длительного кризиса. Департамент международного развития (ДМР) Великобритании определяет «хрупкие государства», как те, где «правительство не может или не выполняет свои основные функции в отношении большинства своего народа, включая бедных». ДМР использует критерий «трудной обстановки», возникающей в результате низкой эффективности государственного правления для типологии «хрупких государств, а также два дополнительных критерия - «политическая воля» и «способность правительства» мобилизовать и эффективно использовать ресурсы для сокращения бедности, включая способность контролировать территорию. Согласно этим критериям, ДМР выделяет следующие категории «хрупких государств»: 1) «Монтеррейский тип» - страны, обладающие относительно сильными способностями и достаточной политической волей; 2) «слабые, но желающие», в которых недостаточная способность государства мобилизовать и эффективно задействовать ресурсы является основным препятствием на пути реализации политики борьбы с бедностью; 3) « сильные, но негибкие», которые обладают достаточными способностями реализовать политические цели; 4) «слабые-слабые», не обладающие ни способностями, ни политической волей. Следует отметить, что критерий «слабости» государства подвергся значительной критике со стороны академических кругов, как очень упрощенный и не отражающий всей сложности ситуации. В свете этого страны-доноры стали практиковать другой критерий - «негибкость» (неустойчивость) государства, исходя из концепции «устойчивости» государства, его способности адаптироваться к меняющимся условиям и восстанавливаться после шоков. Всемирной банк/МАР квалифицируют страны как «хрупкие государства» на базе оценки результатов политики и институтов страны (the Country Policy and Institutional Assessment - CPIA). Страны, оценка которых ниже 3,2 баллов считаются «хрупкими государствами». В настоящее время, согласно критериям Всемирного банка/ МАР, 31 страна и 2 территории относятся к «хрупким государствам». На эти страны/территории приходится лишь 1/6 населения мира, но 1/3 всех смертей в результате заболевания СПИДом и 50\% всех умерших младенцев и детей в возрасте до 5 лет. Уровень бедности в этой группе стран составляет в среднем 54\% населения, а треть населения живет на \$1/день. В 14 из 31 страны и одной территории находятся миротворческие силы ООН, а в 18 странах - миссии ООН по миростроительству.

12. Страны с низкими доходами сгруппированы в 6 кластеров на базе композиционного индекса, оценивающего статус выполнения, и прогресс, достигнутый каждой страной и кластера в реализации ЦРТ. 